\title{
Corrosion Protection of 304 Stainless Steel Bipolar Plates of PEMFC by Coating $\mathrm{SnO}_{2}$ Film
}

\author{
Linghui Yang, Zhenlan Qin,Hongtao Pan, Hong Yun ${ }^{*}$, Yulin Min and Qunjie Xu ${ }^{*}$ \\ Shanghai Key Laboratory of Materials Protection and Advanced Materials in Electric Power, Shanghai \\ Engineering Research Center of Energy-Saving in Heat Exchange Systems, Shanghai University of \\ Electric Power, 2588 Changyang Road, Yangpu District, Shanghai 200090, China \\ *E-mail: yunhong@ shiep.edu.cn; xuqunjie@ shiep.edu.cn
}

doi: $10.20964 / 2017.11 .67$

Received: 28 June 2017 / Accepted: 16 September 2017 / Published: 12 October 2017

Tin oxide $\left(\mathrm{SnO}_{2}\right)$ film was successfully coated on surface of austenite 304 stainless steels (304SS) by combining sol-gel dip-coating method with alcohol thermal method. The coated $\mathrm{SnO}_{2}$ film was used to enhance corrosion resistance of 304SS bipolar plates in a simulated proton exchange membrane fuel cell (PEMFC) environment. Bared 304SS and $\mathrm{SnO}_{2}$ coated 304SS were investigated via EIS, potentiodynamic polarization curves and potentiostatic polarization curves measurements in a simulated PEMFC cathodic, anodic environment, respectively. Compared with the bared 304SS, the corrosion current density for the $\mathrm{SnO}_{2}$ coated 304SS was decreased significantly from $33.22 \mu \mathrm{A} / \mathrm{cm}^{2}$ to $0.1327 \mu \mathrm{A} / \mathrm{cm}^{2}$ in a simulated cathodic environment, and from $75.079 \mu \mathrm{A} / \mathrm{cm}^{2}$ to $0.1581 \mu \mathrm{A} / \mathrm{cm}^{2}$ in a simulated anodic environment. Surface structure and chemical composition of the samples were obtained by SEM, EDX, AFM, XRD and XPS. The result showed that a uniform and compact $\mathrm{SnO}_{2}$ film was coated on the surface of 304SS, which enhanced the corrosion resistance of 304SS in a simulated PEMFC environment.

Keywords: Proton exchange membrane fuel cell (PEMFC); 304 stainless steel; bipolar plate; tin oxide $\left(\mathrm{SnO}_{2}\right)$ film; corrosion

\section{$\underline{\text { FULL TEXT }}$}

(C) 2017 The Authors. Published by ESG (www.electrochemsci.org). This article is an open access article distributed under the terms and conditions of the Creative Commons Attribution license (http://creativecommons.org/licenses/by/4.0/). 